\title{
ARTIKEL
}

\section{Geen VOG, geen werk? Een studie naar VOG-aanvragen en werkkansen na vrijlating ${ }^{*}$}

\author{
Anke Ramakers
}

\section{Inleiding}

Twee jaar na vrijlating is ongeveer de helft van de ex-gedetineerden opnieuw veroordeeld. ${ }^{1}$ Werk kan volgens gedetineerden en hulpverleners de kans op een succesvolle re-integratie verhogen. ${ }^{2}$ Dit verband wordt ook onderbouwd in verscheidene theorieën. Een baan zorgt voor een dagbesteding, inkomen en sociale bindingen, waardoor er minder noodzaak en mogelijkheden zijn voor crimineel gedrag. ${ }^{34}$

De zoektocht naar een baan is voor ex-gedetineerden echter niet zonder uitdagingen. Zo zijn velen laag opgeleid en hebben ze weinig werkervaring. Bovendien kan gedurende detentie dit menselijk (en sociaal) kapitaal verder afnemen. ${ }^{5}$ Ook kan een strafblad re-integratie beperken, doordat het werkgevers afschrikt en bepaalde banen verbiedt. ${ }^{6}$

Deze studie gaat in op de laatstgenoemde barrière. Personen met een strafblad kunnen een baan mislopen wanneer hun aanvraag voor een Verklaring Omtrent het Gedrag (VOG) wordt afgewezen. Het beleid omtrent de VOG heeft als doel risico's voor de samenleving in te perken door personen met een strafblad uit te sluiten van posities die verband houden met hun criminele geschiedenis. Een VOG kan door iedere werkgever worden gevraagd aan de nieuwe werknemer, is verplicht voor steeds meer beroepen, en kan op steeds meer gronden worden afgewezen. ${ }^{7}$ Door deze ontwikkelingen bestaan zorgen over de mate waarin personen in de eerste periode na afloop van hun straf beperkt worden in hun reintegratie. ${ }^{8}$ De kans op een baan wordt laag geacht door het VOG-beleid.

* Dit onderzoek is deels gefinancierd door een subsidie van de Nederlandse Organisatie voor Wetenschappelijk Onderzoek (451-17-020) en gebaseerd op data van screeningsautoriteit Justis en het Prison Project. Het Prison Project is financieel ondersteund door de Universiteit Leiden, het Nederlands Studiecentrum Criminaliteit en Rechtshandhaving (NSCR), de Nederlandse Organisatie voor Wetenschappelijk Onderzoek (NWO) en de Universiteit Utrecht.

1 Dienst Justitiële Instellingen 2019; Linckens \& De Looff 2013.

2 Graffam e.a. 2008.

3 Agnew 1992; Becker 1968; Cohen \& Felson 1979; Miller 2013; Sampson \& Laub 1993.

4 Deels gebaseerd op Ramakers en collega's (2014), zie deze studie voor een meer uitgebreide toelichting.

5 Dirkzwager e.a. 2009; Raphael 2011.

6 Pager 2003.

7 Beleidsregels VOG-NP-RP 2004-2018.

8 Boone 2011, 2012; Bruning 2012; Meijer 2015, 2017; Van 't Zand 2017. 
De invloed van VOG-beleid op baankansen is echter moeilijk empirisch vast te stellen. ${ }^{9}$ Cijfers over het aantal (succesvolle) aanvragen na afloop van een straf zijn onbekend en geven bovendien geen volledig inzicht. ${ }^{10}$ Recent onderzoek laat namelijk zien dat velen in de zoektocht naar werk geen aanvraag indienen, omdat ze inschatten dat de VOG niet zal worden verstrekt. Deze zelfuitsluiting is conform beleid wanneer ze berust op een juiste inschatting; personen met een strafblad solliciteren niet op banen die een te groot risico vormen gezien hun criminele geschiedenis. Zelfuitsluiting is echter onwenselijk wanneer men niet solliciteert vanuit een ongefundeerde angst om te worden afgewezen. ${ }^{11}$ Praktische redenen (te duur, te ingewikkeld) worden ook genoemd als belemmering in het aangaan van een baan waarbij een VOG gevraagd wordt. ${ }^{12}$

Tegelijkertijd zijn er aanwijzingen dat het VOG-beleid geen grote belemmering vormt in de zoektocht naar werk. Personen met een strafblad zijn niet per se geïnteresseerd in het type banen waarbij een VOG gevraagd wordt of beschikken niet over de nodige kwalificaties. ${ }^{13}$ En hoewel alle werkgevers mogen vragen om een VOG, lijken zij dit niet allemaal te weten of zien ze niet altijd het belang ervan in. ${ }^{14}$

\section{Probleemstelling}

Onduidelijk is in welke mate het VOG-beleid de re-integratie op de arbeidsmarkt na afloop van de straf beperkt. Het doel van deze beschrijvende studie is om meer inzicht te krijgen in de rol van de VOG-beleidsregels na afloop van een vrijheidsstraf. Dit inzicht wordt verkregen door voor gedetineerden in kaart te brengen of zij in de eerste jaren na vrijlating werk vonden met of zonder een VOG-aanvraag. Deze informatie vormt een relevante bijdrage in de discussie over de impact van VOG-beleid, die zich baseert op slechts enkele empirische studies. De focus op exgedetineerden komt voort uit het belang van werk onder deze groep en de verwachting dat zij de individuen zijn waartegen het VOG-beleid de samenleving dient te beschermen. Onder deze groep zou daarom sprake kunnen zijn van een grotere belemmering. Als meer bekend is over de rol van VOG-beleid onder ex-

$9 \quad$ Kruize \& Gruter 2016.

10 Een nationale voorlichtingscampagne suggereert dat de kans op een VOG groot is: 'In 2016 kreeg meer dan 99\% van de jongeren die de VOG aanvroegen 'm gewoon' (Kamerstukken II 2016/17, 34550 VI, 98). Nauwkeuriger is om de kans op succes enkel te bekijken voor degenen mét een strafblad en dus de overgrote meerderheid van de aanvragers (zonder strafblad) buiten beschouwing te laten. De laatstgenoemde groep krijgt immers altijd een VOG. Hoewel het percentage dan iets lager ligt (98,3\%), suggereert het - in lijn met de voorlichtingscampagne - dat de kans op een VOG ook voor degenen met een strafblad hoog is. Toch is ook dit percentage misleidend, omdat personen die delicten pleegden buiten de terugkijktermijn het succespercentage verhogen (zie ook Boone \& Kurtovic, 2016).

11 Boekhoorn e.a. 2019; Gosliga 2015; Kurtovic 2015; Van 't Zand 2017.

12 Boekhoorn e.a. 2019.

13 Kruize \& Gruter 2016; Singer-Dekker 1980.

14 Buysse e.a. 2018; Van der Valk e.a. 2006; Singer-Dekker 1980. 
gedetineerden, kan hier tijdens en na detentie beter op worden ingespeeld in hulpverlening die gericht is op het zoeken naar een baan.

In de volgende paragrafen wordt meer inzicht gegeven in het VOG-beleid en eerder onderzoek. De onderzoeksvragen volgen uit dat overzicht, waarna wordt ingegaan op de methoden en de resultaten per onderzoeksvraag. In de conclusie en discussie wordt de betekenis van die resultaten besproken.

\section{De VOG-procedure}

VOG-aanvragen worden door het Centraal Orgaan Verklaring Omtrent Gedrag (COVOG) van screeningsautoriteit Justis van het ministerie van Justitie en Veiligheid getoetst op een objectief en subjectief criterium. ${ }^{15}$ Het objectieve criterium houdt in dat wordt nagegaan of sprake is van strafbare feiten in het Justitieel Documentatie Systeem (JDS) die relevant zijn gelet op het doel van de aanvraag. Als de aanvrager binnen de reguliere terugkijktermijn van vier jaar niet voorkomt in het systeem, wordt de VOG afgegeven. ${ }^{16}$ Wanneer de aanvrager wel voorkomt in het systeem, kan op grond van het subjectieve criterium, waarbij gekeken wordt naar de omstandigheden van het geval (o.a. afdoening van de strafzaak, tijdsverloop, hoeveelheid antecedenten, leeftijd ten tijde van het delict), alsnog worden besloten de VOG af te geven. Ook kan de indiener gedurende het aanvraagproces bewijs van 'goed gedrag' aanleveren. ${ }^{17}$

Het huidige VOG-beleid, waarin aanvragen centraal in plaats van door burgemeesters worden beoordeeld, is sinds 2004 van kracht en is sindsdien meerdere malen gewijzigd. ${ }^{18}$ Sinds 2008 mag iedere werkgever een VOG aanvragen. ${ }^{19}$ Ook is het sindsdien mogelijk om relevante justitiële gegevens die buiten de geldende terugkijktermijn vallen bij de beoordeling te betrekken en wordt de terugkijktermijn verlengd met de periode dat de aanvrager in detentie heeft doorgebracht. Later is continue screening ingevoerd voor specifieke beroepsgroepen, namelijk de taxibranche en de kinderopvang. ${ }^{20}$ Een uitzondering op deze voorbeelden van uitbreiding is, dat de terugkijktermijn voor personen die ten tijde van hun aanvraag jonger dan 23 jaar waren, in 2013 is ingekort tot twee jaar, mits geen sprake is van zedendelicten, ernstige geweldsdelicten of terroristische misdrijven. ${ }^{21}$

Er is een kortere terugkijktermijn van twee jaar voor de meeste jonge delictsplegers ( $<23$ jaar) en zedendelicten worden altijd meegenomen.

Beleidsregels VOG-NP-RP 2018; Wildemors 2012.

Beleidsregels VOG-NP-RP 2004.

Beleidsregels VOG-NP-RP 2008.

Beleidsregels VOG-NP-RP 2012; Kamerstukken II 2008/9, 29911, nr. 25; Kamerstukken II 2010/11, 33000-VI nr.73.

1 Beleidsregels VOG-NP-RP 2013. 


\section{Eerder empirisch onderzoek}

Enkele uitzonderingen daargelaten was er tot voor kort weinig aandacht voor het VOG-beleid in empirische studies. In 1980 concludeerde Singer-Dekker op basis van enquêtes onder professionals (54 inrichtingswerkers, 134 maatschappelijk werkers) dat veel personen met een strafblad zich zorgen maakten over het vinden van werk, maar niet zozeer over een VOG. ${ }^{22}$ Een minderheid van de professionals gaf aan dat cliënten vaak een VOG moesten overleggen, dat een VOG geweigerd was of dat cliënten zich hadden teruggetrokken nadat een VOG gevraagd werd in een sollicitatieprocedure. ${ }^{23}$ Ook bleken velen slecht op de hoogte van het toenmalige beleid. ${ }^{24}$ Op basis van enquêtes onder werkgevers $(\mathrm{N}=80)$ stelde men vast dat minder dan een derde bij een sollicitatie weleens had gevraagd om een VOG en een vijfde niet op de hoogte was van het bestaan ervan. ${ }^{25}$

Recente studies lijken voor de huidige tijd meer bewijs te vinden voor een negatieve invloed van het VOG-beleid op werkkansen. Van 't Zand vond op basis van longitudinaal kwalitatief onderzoek onder 31 jongvolwassenen met een licht tot zwaar strafblad, dat ongeveer twee derde ervaring had met uitsluiting van werk na een VOG-screening en een kwart met uitsluiting van een opleiding. ${ }^{26}$ Naast ervaren uitsluiting, vond zij bewijs voor geanticipeerde uitsluiting met zelfuitsluiting als gevolg. De jongvolwassenen vermeden bepaalde functies, omdat ze, mogelijk onterecht, anticipeerden op een VOG-weigering. Daarnaast gaven sommigen aan dat ze minder solliciteerden of zich zelfs volledig wilden onttrekken aan de arbeidsmarkt om afwijzing te voorkomen. Degenen met werk waren veelal niet tevreden over de kwaliteit van de baan. De jongvolwassenen bleken bovendien slecht op de hoogte te zijn van de exacte regelgeving en dat gold eveneens voor andere betrokkenen, zoals ouders en professionals. Tussen professionals leken ook grote verschillen te bestaan in betrokkenheid bij het begeleiden van een VOG-aanvraag. ${ }^{27}$

Gosliga vond in opdracht van het ministerie van Justitie en Veiligheid in een verkennend onderzoek naar de beeldvorming omtrent VOG-aanvragen onder 54 risicojongeren en 73 jeugdprofessionals eveneens bewijs voor zelfuitsluiting en een kennistekort op het gebied van het VOG-beleid. ${ }^{28}$ Verwachtingen omtrent VOGaanvragen bleken door beide partijen niet gebaseerd te worden op overheidsbronnen, maar op kennis uit hun eigen netwerk. Deze vrienden en professionals bleken dikwijls te pessimistisch te zijn. In combinatie met de bevinding dat veel jongeren afwijzing te allen tijde willen voorkomen, zou dit ervoor zorgen dat de impact van het VOG-beleid groter is dan wordt beoogd. 
Boekhoorn en collega's vonden bewijs voor zelfuitsluiting onder mbo'ers en vmbo-uitstromers. ${ }^{29} \mathrm{Ze}$ onderzochten in hoeverre deze jongeren geen VOG-aanvraag voor werk of een stageplek indienden omdat zij verwachtten deze niet te zullen krijgen. Van degenen met een strafblad bleek $17 \%$ een VOG-aanvraag te hebben ingediend en het aandeel VOG-aanvragen nam af naarmate de ernst van de gepleegde delicten toenam. De onderzoekers stellen dat dit de preventieve werking van het VOG-instrument weergeeft en dus eerder terechte dan onterechte mijding betreft. Slechts $3 \%$ van degenen met een strafblad had weleens een VOG-aanvraag gemeden ( $\mathrm{N}=1550-1700)$ en het percentage VOG-afwijzingen was zeer klein (0,069\%: 1 op de 126 VOG-aanvragen met een strafblad). Een simulatiemodel toonde aan dat dit percentage laag bleef wanneer de VOG-mijders wel een aanvraag zouden indienen $(0,123 \%)$. Hoewel het niet mogelijk bleek om op individueel niveau na te gaan of de inschatting van de VOG-mijders terecht was, concludeerden de onderzoekers op basis van bovenstaande informatie dat het gros van de VOG-mijders met een strafblad te pessimistisch lijkt over de aanvraag. Opvallend was dat $2 \%$ van de jongeren zonder strafblad een VOG-aanvraag had gemeden ( $N=7350-7500)$. Er was dus meer sprake van onterechte uitsluiting onder jongeren zonder strafblad.

Recent vonden Buysse en collega's dat niet alle werkgevers evenveel belang hechten aan screening in een onderzoek in de Benelux en Duitsland onder werkgevers met sollicitanten uit buurlanden $(\mathrm{N}=478) .{ }^{30}$ Ongeveer een derde van de ondervraagde werkgevers gaf aan te screenen op strafblad. Onder Nederlandse werkgevers $(\mathrm{N}=103)$ lag dit percentage met $22 \%$ iets lager. ${ }^{31}$ Het gebrek aan screening als standaardprocedure en gebrek aan kennis over de mogelijkheden hiertoe werden genoemd als belangrijke redenen. Daarnaast bestond onder een deel van de werkgevers en overig relevante actoren twijfel over het belang van de VOG-procedure. $^{32} \mathrm{Zo}$ gaf de helft van degenen die verplicht waren om een VOG te verzoeken, aan om hiervan af te zien indien men daarin een vrije keuze zou hebben. Anderen trokken vergelijkbare conclusies op basis van onderzoek naar vrijwilligersorganisaties. ${ }^{33}$ Deze studies lieten daarnaast zien dat werkgevers beperkte kennis hadden over welke informatie binnen welke termijn wordt meegewogen in de screening.

Waar de zojuist beschreven studies de gevolgen van VOG-beleid onderzochten op basis van de verwachtingen en ervaringen van personen met een strafblad, professionals en werkgevers, deden Kruize en Gruter dit door de werkkansen van een groep personen van wie de VOG-aanvraag afgewezen was te vergelijken met twee controlegroepen (CG). ${ }^{34}$ Ze richtten zich op onderwijspersoneel en taxichauffeurs, beroepsgroepen waar een VOG verplicht is, en gebruikten registratiedata

30 Buysse e.a. 2018.

31 Buysse e.a. 2018, berekening op basis van tabel 4.1 en 4.2.

32 Van der Valk e.a. 2006.

33 Van der Klein, Los \& Verwijs 2013.

34 Kruize \& Gruter 2016. 
over VOG-aanvragen en arbeidsparticipatie. ${ }^{35}$ Voorafgaand aan de aanvraag had de groep VOG-geweigerd ( $\mathrm{N}=200)$ een lagere arbeidsparticipatie dan de groep die een VOG had ontvangen (CG1 N=200), maar was deze actiever dan de groep met vergelijkbare antecedenten die geen aanvraag had ingediend (CG2 N=200). In het jaar na de aanvraag daalde bij de groep VOG-geweigerd de arbeidsparticipatie van $72 \%$ naar $63 \%$. Bij degenen met een VOG was geen daling zichtbaar (90\%) en bij de groep met vergelijkbare antecedenten was een kleine daling waar te nemen van 49\% naar 46\% (CG2). Kruize en Gruter zien in de timing van de daling in arbeidsparticipatie (in het jaar na de VOG-weigering) bewijs voor de interpretatie dat de VOG-weigering de arbeidsparticipatie verslechtert. ${ }^{36}$ Ze stellen echter ook dat gezien het onderzoeksdesign voorzichtigheid is geboden bij een dergelijke causale interpretatie. Een vergelijking van de jaarlijkse arbeidsuitkomsten wordt bovendien gehinderd door verschillen tussen de drie groepen. ${ }^{37}$ De eerste controlegroep bestaat grotendeels uit personen zonder criminele geschiedenis en van de tweede controlegroep is onbekend of ze op zoek zijn naar werk. Groepsverschillen in arbeidsparticipatie kunnen daardoor niet simpelweg worden toegeschreven aan een VOG-weigering.

\section{Onderzoeksvragen}

Het doel van deze studie is om meer inzicht te krijgen in de rol van de VOGbeleidsregels onder ex-gedetineerden. Eerdere studies over het VOG-beleid zijn schaars en trekken verschillende conclusies. De kwalitatieve studies onder jongeren met een strafblad lijken een relatief grotere invloed toe te schrijven aan het VOG-beleid. De enkele kwantitatieve studies zijn geschikter om inzicht te geven in de omvang van de onderzochte problematiek en zien het VOG-beleid minder als een belemmering. De specifieke kenmerken van deze studies (focus op jongeren, focus op sectoren met VOG-verplichting) beperken echter de generaliseerbaarheid van de conclusies. Ook bleef onderbelicht in hoeverre respondenten werk vonden zonder een VOG, terwijl dit ook inzicht geeft in het belang van de VOG. De huidige studie vormt een bijdrage aan de literatuur door als eerste voor een grote groep gedetineerden na te gaan in hoeverre zij na vrijlating:

1 een (succesvolle) VOG-aanvraag indienen;

2 in staat zijn werk te vinden;

3 dit werk vinden zonder VOG-aanvraag.

35 Kruize en Gruter (2016) verrichten in opdracht van het ministerie van Justitie en Veiligheid een onderzoek naar de beleidstheoretische overwegingen achter de VOG, de toepassing van het beleid in de praktijk en de effectiviteit van de VOG. Gezien de vraagstelling van de huidige studie beschrijf ik het laatste onderdeel waarin aan de hand van kwantitatieve methoden de effectiviteit van het beleid wordt geprobeerd vast te stellen gelet op arbeidsuitkomsten.

36 Wat betreft criminaliteit vinden Kruize en Gruter (2016) dat de groep VOG-geweigerd een daling in criminaliteit laat zien.

37 Arbeidsparticipatie werd gemeten als minimaal 90 dagen per jaar gewerkt in loondienst en/of geregistreerd staan als fiscaal zelfstandige. 


\section{Methode}

In deze kwantitatieve beschrijvende studie worden de onderzoeksvragen beantwoord aan de hand van longitudinale data over een grote groep ex-gedetineerden.

\section{Databronnen}

Er wordt gebruikgemaakt van twee databronnen; gestructureerde interviews met ex-gedetineerden die deel hebben genomen aan het Prison Project-onderzoek en VOG-aanvragen van diezelfde groep ex-gedetineerden afkomstig van screeningsautoriteit Justis van het ministerie van Justitie en Veiligheid.

Het Prison Project is een longitudinale dataverzameling onder mannen die tussen oktober 2010 en april 2011 in voorlopige hechtenis instroomden in een huis van bewaring. Zij zijn allen in Nederland geboren, tussen de 18 en 65 jaar oud en hadden geen zware psychische problemen. In totaal namen 1.904 mannen deel aan het eerste interview. Zij zijn tijdens en na vrijlating meerdere malen benaderd voor vervolgmetingen. Meer dan de helft van deze mannen is in detentie en twee jaar na vrijlating geïnterviewd $(\mathrm{N}=964)$. Enkelen gaven geen toestemming voor het opvragen van justitiële gegevens en daarom hebben de analyses betrekking op 931 mannen. In beide interviews zijn vragen gesteld over diverse levensdomeinen, zoals crimineel gedrag, werk- en woonsituatie, gezondheid en het sociale netwerk. ${ }^{38}$

Zoals hierboven beschreven, beoordeelt de afdeling COVOG van screeningsautoriteit Justis of een VOG-aanvraag wordt toegekend. Justis stelt vast of de aanvrager een strafblad heeft en deelt met diegene of er bezwaren zijn gezien het specifieke doel van de aanvraag. De verklaring bevat geen specifieke informatie over de criminele geschiedenis en is enkel via de aanvrager beschikbaar voor werkgevers. ${ }^{39}$ Justis is voor het Prison Project-onderzoek nagegaan of deelnemers een VOG-aanvraag hebben ingediend. Indien dit het geval was, werd per aanvraag de volgende informatie verstrekt: uitkomst VOG-aanvraag: afgifte of weigering, datum afgifte of weigering en beschikbare informatie over de soort functie waarvoor de VOG is aangevraagd.

\section{Onderzoeksstappen}

In het Prison Project is een kalendermethode gebruikt om voor de eerste twee jaar na vrijlating per periode van vier maanden vast te stellen of iemand werk rapporteerde als belangrijkste bezigheid en of het werk als zelfstandige, werk in loondienst of zwart werk betrof. Deze uitsplitsing komt voort uit de bevinding van eerder onderzoek dat veel ex-gedetineerden aan de slag gaan als zelfstandige of zwart werken. ${ }^{40}$ Met name zwart werk kan een uitweg vormen voor personen die omwille van hun strafblad worden uitgesloten van wit werk. Werkdata zijn voor 787 van de 931 respondenten bekend. In de meeste gevallen zijn de missende

39 Voor een voorbeeld van een VOG zie: www.justis.nl/binaries/Voorbeeld\%20VOG\%202019_ tcm34-84795.pdf.

40 Fletcher 2008; Ramakers e.a. 2017. 
waarden ontstaan doordat verkeerde kalenderdata zijn ingevuld door de interviewer $(\mathrm{N}=111)$. Er lijkt daardoor geen sprake te zijn van selectiviteit in de missende waarden onder deelnemers. De gedetineerden die deelnamen aan het Prison Project-onderzoek zijn op veel achtergrondkenmerken vergelijkbaar met degenen die niet deelnamen aan de eerste meting in detentie of uitvielen in de vervolgmetingen na vrijlating. ${ }^{41}$ Wel hebben deelnemers minder vaak dan niet-deelnemers al eens in detentie gezeten (58 versus $73 \%$ ) en wonen ze minder vaak in een grote stad (25 versus 34\%). Van belang is om dit bij de interpretatie van resultaten in gedachten te houden.

Aan de hand van VOG-data en detentie-uitstroomdatums is vastgesteld of iemand sinds vrijlating een VOG-aanvraag heeft ingediend, of de aanvraag is toegekend en wanneer dit besluit is genomen. ${ }^{42}$ In deze studie wordt enkel naar de eerste aanvraag na vrijlating gekeken en naar aanvragen die ingediend zijn ten behoeve van werk (in loondienst of als zelfstandige). ${ }^{43}$ De onderzoeksperiode voor VOG-aanvragen verschilt per gedetineerde en is afhankelijk van de uitstroomdatum. De maximale onderzoeksperiode is zes jaar, omdat Justis eind 2016 de VOG-data heeft verstrekt en de eerste gedetineerden vrijkwamen eind 2010. De meeste gedetineerden kwamen vrij in 2011. Voor hen is de onderzoeksperiode dus ongeveer vijf jaar.

Om inzicht te krijgen in de rol van de eerder toegelichte terugkijktermijn wordt in de paragraaf over de resultaten apart aandacht besteed aan ingediende aanvragen binnen twee jaar na vrijlating, binnen vier jaar na vrijlating en binnen de maximale onderzoeksperiode (vrijlating - december 2016). Welke terugkijktermijn in individuele gevallen geldt, is afhankelijk van datum van veroordeling, of iemand nieuwe delicten pleegt en allerlei eerder genoemde aanvraag- en aanvragerspecifieke factoren. ${ }^{44}$ Sinds 2008 wordt de terugkijktermijn verlengd met de detentieperiode. In deze studie wordt de datum van uitstroom uit detentie daarom als ruwe startdatum van de reguliere, vierjarige terugkijktermijn beschouwd. Omdat werkervaringen kunnen worden onderzocht voor de eerste twee jaar na afloop van de straf, wordt ook apart naar die periode gekeken.

\section{Resultaten}

\section{In hoeverre dienen ex-gedetineerden een (succesvolle) VOG-aanvraag in?}

Tabel 1 toont voor de verschillende periodes hoeveel aanvragen zijn ingediend en wat de kans is op een succesvolle VOG-aanvraag. Uit deze cijfers blijkt dat slechts een klein deel van de ex-gedetineerden een aanvraag heeft ingediend na vrijlating. De tweede kolom betreft de aanvragen die binnen twee jaar zijn ingediend. In die

41 Dirkzwager e.a. 2018.

42 In- en uitstroomdata zijn afkomstig uit het justitiële informatiesysteem TULP (tenuitvoerlegging van vrijheidsbenemende straffen en maatregelen in penitentiaire inrichtingen) van de Dienst Justitiële Inlichtingen.

43 De aanvragen die betrekking hebben op vrijwilligerstaken $(\mathrm{N}=6)$, licenties $(\mathrm{N}=1)$ of een opleiding $(\mathrm{N}=1)$ zijn buiten beschouwing gelaten.

44 Beleidsregels VOG-NP-RP 2018. 
periode hebben 23 ex-gedetineerden een aanvraag ingediend (2,5\%) en vijf van hen een VOG ontvangen. Twee jaar later is het aantal aanvragen bijna verdubbeld naar $42 \%$ en wordt $36 \%$ toegekend. Na vier jaar hebben nog eens zestien ex-gedetineerden een VOG-aanvraag ingediend. De laatste kolom laat zien dat gedurende de totale onderzoeksperiode 58 aanvragen zijn ingediend (6,2\%), waarvan de helft is toegekend. De kans dat men een aanvraag indient en de kans dat deze toegekend wordt, lijken beide toe te nemen naarmate de detentieperiode langer geleden is.

Tabel 1 VOG-aanvragen en uitkomsten $(N=931)$

\begin{tabular}{lrrrrrr}
\hline & $\begin{array}{c}\text { Binnen 2 jaar } \\
\text { na vrijlating }\end{array}$ & \multicolumn{2}{c}{$\begin{array}{c}\text { Binnen 4 jaar } \\
\text { na vrijlating }\end{array}$} & \multicolumn{2}{c}{$\begin{array}{c}\text { Totaal aantal aanvragen } \\
\text { (vrijlating - tot dec. 20 I6) }\end{array}$} \\
\hline & $\mathrm{N}$ & $\%$ & $\mathrm{~N}$ & $\%$ & $\mathrm{~N}$ & $\%$ \\
$\begin{array}{l}\text { Geen aanvraag } \\
\text { ingediend }\end{array}$ & 908 & $97,5 \%$ & 889 & $95,5 \%$ & 873 & $93,8 \%$ \\
$\begin{array}{l}\text { Aanvraag } \\
\text { ingediend }\end{array}$ & 23 & $2,5 \%$ & 42 & $4,5 \%$ & 58 & $6,2 \%$ \\
$\quad \begin{array}{l}\text { Afgewezen } \\
\text { Toegekend }\end{array}$ & 18 & $78,3 \%$ & 27 & $64,3 \%$ & 29 & $50,0 \%$ \\
\hline ' Datum van vrijlating verschilt per persoon. De meeste gedetineerden kwamen vrij in 20II.
\end{tabular}

Figuur 1 geeft in meer detail het verloop van aanvragen en toegekende aanvragen weer gedurende de onderzoeksperiode. $\mathrm{Na}$ 8, 24 en 56 maanden is een piek in aanvragen zichtbaar. Het kleine aantal aanvragen maakt echter dat voorzichtigheid is geboden bij het interpreteren van de bevindingen als trends. Ook is enige terughoudendheid op zijn plaats, omdat de gehanteerde terugkijktermijn in individuele gevallen kan afwijken. Desondanks is het opvallend, dat ongeveer vier jaar na vrijlating de meeste aanvragen worden toegekend. Dit doet vermoeden dat het verstrijken van de terugkijktermijn daarmee te maken heeft.

\section{Figuur 1 Aantal VOG-aanvragen na vrijlating $(\mathrm{N}=58)$}

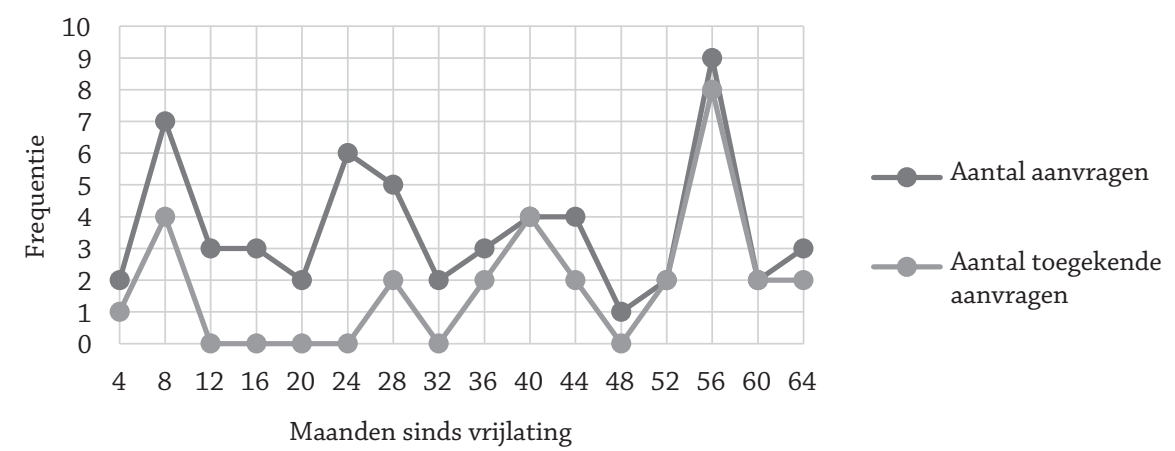




\section{In hoeverre vinden ex-gedetineerden werk?}

Figuur 2 laat de gerapporteerde arbeidsparticipatie in de eerste twee jaar na vrijlating zien. ${ }^{45}$ Gedurende de eerste vier maanden na vrijlating heeft $36 \%$ van de ex-gedetineerden werk gerapporteerd. Dit percentage stijgt naar $43 \%$ na twintig maanden. Over de hele onderzoeksperiode van twee jaar bekeken, rapporteert $55 \%$ van de ex-gedetineerden minimaal één keer werk. Uit deze cijfers volgt dat bijna twee derde van de werkende ex-gedetineerden dit werk binnen de eerste vier maanden vindt $(36 / 55=65,5 \%)$.

Drie typen werk kunnen worden onderscheiden. In de eerste vier maanden rapporteert $18 \%$ van de ex-gedetineerden een baan in loondienst, $10 \%$ procent werk als zelfstandige en $8 \%$ zwart werk. Het percentage ex-gedetineerden dat werkzaam is in loondienst stijgt naar maximaal $26 \%$ na twintig maanden. Het percentage zelfstandigen schommelt tussen de 10 en $11 \%$ en het percentage dat zwart werkt, neemt met $2 \%$ af gedurende de onderzoeksperiode. Loondienst is dus de meest voorkomende werksoort; de helft van de werkende ex-gedetineerden rapporteert een baan in loondienst in de eerste vier maanden en dit percentage stijgt naar maximaal $61 \%$ na twintig maanden.

De verschillende periodes geven ook inzicht in de stabiliteit van de werksituatie gedurende de eerste twee jaar na vrijlating. Uit verdere analyse blijkt dat degenen die werk rapporteren, dit vaak doen in meerdere opeenvolgende periodes. Maar liefst $45 \%$ rapporteert werkzaam te zijn geweest in alle onderzochte periodes, $15 \%$ in vijf periodes en $10 \%$ rapporteert werk in vier periodes. Onzeker is of het in de aaneengesloten periodes om dezelfde baan gaat en tussenpozen zonder werk binnen een periode zijn niet uit te sluiten. De voorzichtige conclusie is dat veel werkenden hun baan vast kunnen houden of in staat zijn op korte termijn alternatief werk te vinden.

In overeenstemming met die interpretatie rapporteren veruit de meeste werkende ex-gedetineerden gedurende de onderzoeksperiode hetzelfde type werk. Voor iets meer dan een tiende van de werkende ex-gedetineerden $(11,4 \%)$ is meer bewijs voor een baanwissel, aangezien zij meerdere typen werk rapporteren gedurende de onderzoeksperiode. Ongeveer de helft van hen wisselt loondienst af met werk als zelfstandige, de andere helft wisselt loondienst af met zwart werk.

45 Als gevolg van eerder besproken missende waarden op de werkvariabelen hebben de analyses over gerapporteerd werk betrekking op 787 personen en 18 aanvragen die gedaan zijn in de eerste twee jaar na vrijlating. 
Figuur 2 Percentage werkenden in de eerste twee jaar na vrijlating (N=787)

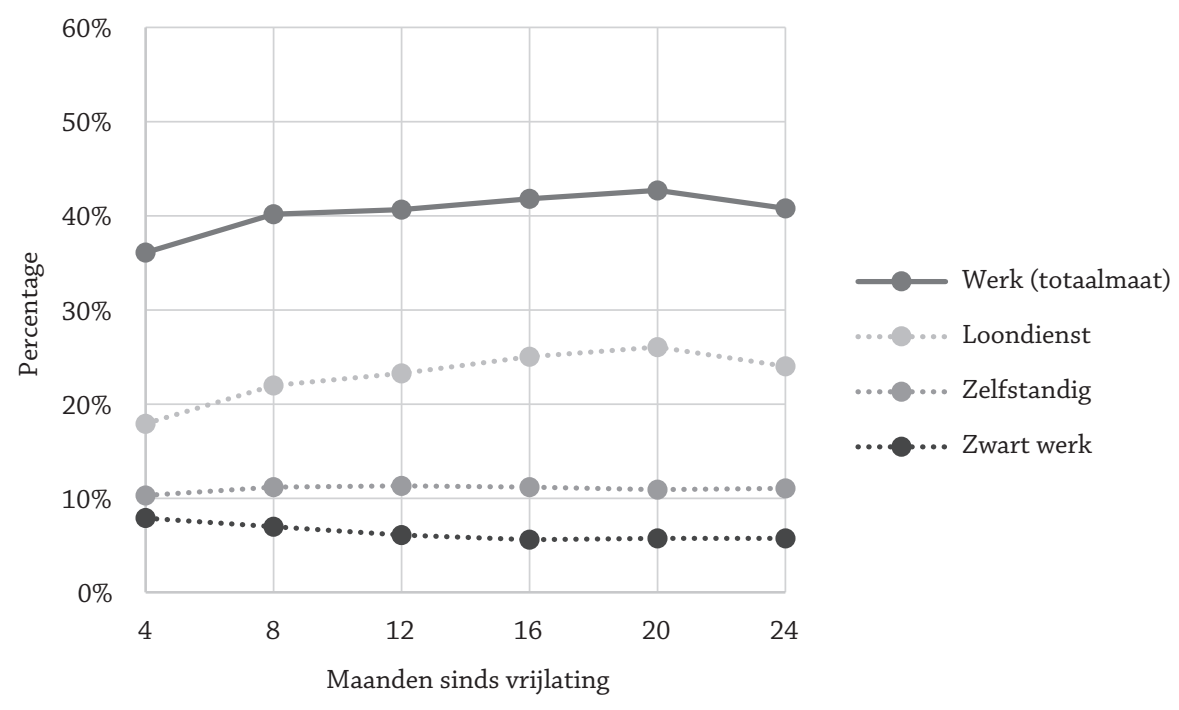

In hoeverre vinden ex-gedetineerden werk zonder VOG-aanvraag?

Slechts 2,5\% heeft een VOG-aanvraag ingediend binnen twee jaar na vrijlating en meer dan de helft vond werk in die periode. Dit laat al zien dat vrijwel alle werkende ex-gedetineerden dit werk hebben gevonden zonder een aanvraag te hoeven doen.

Deze relatie wordt ook preciezer bekeken door in te zoomen op degenen die een VOG-aanvraag hebben ingediend. Logischerwijs zou men verwachten dat de aanvragen zijn ingediend door ex-gedetineerden die minstens één periode werk rapporteren. Tabel 2 laat zien dat dit het geval is bij dertien van de achttien VOGaanvragen. Slechts vier van die aanvragen zijn toegekend.

Ook is bekeken wat de werkkansen zijn nadat de VOG is verstrekt $(\mathrm{N}=4)$ of afgewezen ( $\mathrm{N}=14$ ). Drie van de vier ex-gedetineerden die een VOG ontvangen, blijken daarna daadwerkelijk werk te rapporteren. Hoewel het aannemelijk is dat dit dezelfde functie betreft als waarvoor de VOG-aanvraag is ingediend, is het op basis van de beschikbare data niet mogelijk dit met zekerheid vast te stellen. Er kan dus ook sprake zijn van alternatief werk. De bevinding dat alle drie deze personen werk in loondienst rapporteren, sluit aan bij de interpretatie dat het de functie betreft waar de VOG voor is aangevraagd.

$\mathrm{Na}$ een VOG-weigering blijkt de meerderheid in staat om alternatief werk te vinden; acht van de veertien afgewezen personen vinden ander werk. Vijf van hen hebben werk in loondienst gevonden en de overige drie zijn aan de slag gegaan als zelfstandige. Geen van hen rapporteert zwart werk. De VOG-weigering lijkt deze personen dus niet uit te hebben gesloten van legaal werk. De overige zes rapporteren geen enkel type werk na de weigering. Dit zou kunnen duiden op zelfuitsluiting, maar andere verklaringen lijken ook plausibel. Uit verdere analyse blijkt dat drie van hen aan het einde van de twee jaar de VOG-aanvraag indienden. Zij heb- 
ben mogelijk na afloop van de onderzoeksperiode alsnog werk gevonden. Bij twee van de drie overige ex-gedetineerden lijken er alternatieve verklaringen te zijn voor hun inactiviteit; één van hen rapporteert een nieuwe detentie en de ander dat hij terug naar school is gegaan.

Tabel 2 VOG-aanvragen en gerapporteerd werk in de eerste twee jaar na vrijlating $(N=787)$

\begin{tabular}{lrrrr}
\hline & Geen werk & & Werk & \\
& N & $\%$ & N & $\%$ \\
\hline Geen aanvraag & 353 & 98,6 & 416 & 97 \\
Aanvraag toegekend & 0 & 0 & 4 & 1 \\
Aanvraag afgewezen & 5 & 1,4 & 9 & 2 \\
Totaal & 358 & 100 & 429 & 100 \\
\hline
\end{tabular}

\section{Conclusie \& discussie}

Het is onduidelijk in hoeverre het VOG-beleid lage werkkansen na afloop van de straf kan verklaren. De VOG-beleidsregels hebben als doel risico's voor de samenleving in te perken door personen met een strafblad uit te sluiten van posities die verband houden met hun delictsgeschiedenis. Een onbedoeld gevolg kan zijn dat zij geen werk vinden en stagneren in hun re-integratieproces. Deze beschrijvende studie probeerde hier meer inzicht in te krijgen door na te gaan of gedetineerden na vrijlating aanspraak maakten op een VOG, werk vonden en of zij dit werk vonden zonder een VOG nodig te hebben.

Slechts $6 \%$ van de ex-gedetineerden bleek een VOG te hebben aangevraagd gedurende de eerste jaren na vrijlating. Dit percentage lijkt laag, gezien de elders beschreven zorgen over het VOG-beleid ${ }^{46}$ en een eerder gevonden aanvraagpercentage onder jongeren met een strafblad. ${ }^{47}$ Mogelijk is het kleine aantal VOGaanvragen deels te verklaren door de verwachting van ex-gedetineerden en hulpverleners dat zij geen VOG zullen ontvangen. Gezien hun recente detentieverleden kan die inschatting dikwijls terecht en conform beleid zijn. ${ }^{48}$ Tegelijkertijd blijkt uit de resultaten dat een recent detentieverleden niet automatisch leidt tot een afwijzing; in de eerste vier jaar na vrijlating werd een derde van de ingediende aanvragen toegekend. Deze kans lijkt te stijgen na de terugkijktermijn van vier jaar. Hieruit volgt dat de pessimistische houding onder een deel van degenen met een strafblad en hulpverleners wellicht moet worden bijgesteld. ${ }^{49}$ Wel maken het kleine aantal VOG-aanvragen en individuele verschillen in te hanteren terugkijktermijn dat enige terughoudendheid is vereist bij het interpreteren van de cijfers als trends. 
Binnen twee jaar na vrijlating rapporteerde slechts 55\% werk op enig moment. Deze bevinding komt overeen met (inter)nationaal onderzoek naar werkervaringen na afloop van een vrijheidsstraf. ${ }^{50}$ Werkende ex-gedetineerden vonden dit werk vaak kort na vrijlating en leken dit werk vast te kunnen houden. Loondienst was veruit de meest gerapporteerde werksoort, maar werk als zelfstandige en zwart werk werd overeenkomstig met eerder onderzoek ook gerapporteerd door een substantiële groep ex-gedetineerden. ${ }^{51}$

Vrijwel alle werkende ex-gedetineerden waren in staat een baan te vinden zonder VOG te overleggen. Hun werkgevers verzochten niet om een VOG. Hiermee bouwt deze studie voort op eerdere onderzoek dat vaststelde dat veel werkgevers niet weten dat ze een VOG mogen vragen of het belang ervan niet inzien, maar is niet hun werkelijke gedrag bij sollicitaties onderzocht. ${ }^{52}$ Bij de kleine aantallen die hier bestudeerd konden worden, leek een VOG-weigering bovendien niet te hebben geleid tot stoppen met werken of verdringing naar het informele circuit. Het VOG-beleid lijkt niet in de weg te staan aan het vinden van werk.

Toch sluiten de resultaten niet uit dat ex-gedetineerden beïnvloed zijn door het VOG-beleid. Eén mechanisme is al genoemd: het kleine aantal VOG-aanvragen is deels te verklaren door bedoelde zelfuitsluiting van ex-gedetineerden. Een tweede manier waarop men beïnvloed kan zijn door het beleid is door een onbedoelde vorm van zelfuitsluiting: er wordt geen aanvraag ingediend omdat onterecht gedacht wordt dat de VOG niet zal worden verstrekt. ${ }^{53}$ Als laatste kan sprake zijn van bewuste vermijding van functies met een VOG-verplichting of functies waarbij men verwacht een VOG-verzoek te ontvangen.

Van onterechte zelfuitsluiting zou sprake kunnen zijn onder de grote groep exgedetineerden die geen werk rapporteerden. De grootschalige studie van Boekhoorn en collega's liet echter zien dat slechts $3 \%$ van de jongeren met een strafblad bewust een VOG-aanvraag hadden vermeden, omdat ze verwachtten deze niet te zullen ontvangen. Bij een nóg kleiner deel van hen betrof dit onterechte zelfuitsluiting. Toekomstig onderzoek zal moeten uitwijzen of deze resultaten te generaliseren zijn naar andere groepen met een strafblad zoals ex-gedetineerden. Relevant in dit verband is om ook alternatieve verklaringen voor de hoge mate van inactiviteit onder ex-gedetineerden te onderzoeken. Een onderbelichte verklaring voor het kleine aantal VOG-aanvragen en werkkansen onder deze groep is dat velen niet op zoek zijn naar werk. Zij willen of kunnen niet werken en hiervan was vaak al sprake voorafgaand aan hun straf. ${ }^{54}$

Van een negatieve beleidsinvloed is sprake wanneer men door het mijden van functies met een VOG-verplichting geen andere baan kan vinden of terechtkomt in relatief slechtere banen. ${ }^{55}$ De huidige bevindingen spreken het eerste tegen; voor veel ex-gedetineerden lijkt het VOG-beleid geen belemmering te vormen bij het vinden van werk. Wat betreft baankwaliteit blijkt uit de resultaten dat werk in

50 Bäckman e.a. 2017; Beerthuizen e.a. 2016; Berg \& Huebner 2011; Visher e.a. 2008.

51 Fletcher 2008.

52 Buysse e.a. 2018; Van der Valk e.a. 2006.

53 Boekhoorn e.a. 2019; Gosliga 2015; Van 't Zand 2017.

54 Apel \& Sweeten 2010; Bushway 2006; Ramakers e.a. 2015.

55 Van 't Zand 2017. 
loondienst het meest voorkomt (versus werk als zelfstandige en zwart werk). Ook lijken degenen die werk rapporteren meestal voor langere periodes aan het werk te zijn. Aangezien eerder onderzoek vond dat stabiel werk cruciaal is voor recidivevermindering zijn deze resultaten hoopgevend. ${ }^{56}$ Meer diepgaand onderzoek naar baankenmerken na vrijlating is echter gewenst.

Een vergelijking tussen het type banen waar personen met een strafblad een VOG voor aanvragen en het type banen waarin ze terechtkomen geeft inzicht in eventuele verschillen in baankwaliteit. In de huidige studie beperkte het kleine aantal aanvragen de meerwaarde van een dergelijke vergelijking. Een andere beperking is dat niet kon worden nagaan of het gerapporteerde werk dezelfde baan betrof als waarvoor diegene eerder een aanvraag had ingediend. Indien vervolgonderzoek wel die koppeling kan maken, wordt inzichtelijk of de banen die gevonden worden middels een VOG-screening van andere kwaliteit zijn dan overige banen.

De gedetineerden die deelnamen aan het Prison Project-onderzoek zijn op veel kenmerken representatief voor de geselecteerde gedetineerdenpopulatie. Wel zijn gedetineerden met een eerdere detentie-ervaring, en dus zwaarder strafblad, ondervertegenwoordigd. ${ }^{57}$ In werkelijkheid kunnen de werkkansen dus nog wat lager zijn. Onduidelijk is in hoeverre de resultaten te generaliseren zijn naar andere groepen gedetineerden, zoals vrouwen en jongeren. Mogelijk zal hen in de zoektocht naar werk vaker een VOG worden gevraagd. Vrouwen werken vaker in de zorgsector waar een VOG verplicht is. Opleidingen mogen geen VOG eisen, maar stage- en leerbedrijven wel en dit kan ervoor zorgen dat jongeren keuzes (onnodig) aanpassen. ${ }^{58}$

Samenvattend, deze studie liet zien dat weinig ex-gedetineerden een VOG-aanvraag indienden en iets meer dan de helft van de totale groep werk vond. Hieruit volgt dat hoewel iedere werkgever mag vragen om een VOG lang niet iedereen dit doet. Daarnaast bleek dat men - conform beleid - ook binnen de terugkijktermijn kans had op een VOG en meer kans maakte op een succesvolle aanvraag naarmate men langer vrij was. Hoewel de bevindingen van deze studie niet uitsluiten dat het VOG-beleid in individuele gevallen verstrekkende gevolgen kan hebben voor de arbeidsre-integratie, lijken zij de rol van dit beleid als geheel te nuanceren. Dit is relevant voor zowel de personen met een strafblad als de hulpverleners die hen bijstaan in het re-integratieproces. Tegelijkertijd is onderzoek dat inzicht kan geven in de verklarende mechanismen achter de huidige bevindingen gewenst om hen beter te kunnen voorlichten.

\section{Referenties}

Agnew, R., 'Foundation for a general strain theory of crime and delinquency', Criminology 1992-30(1), p. 47-88.

Apel, R. \& G. Sweeten, 'The impact of incarceration on employment during the transition to adulthood', Social Problems 2010-57(3), p. 448-479. 
Bäckman, O., F. Estrada \& A. Nilsson, 'Locked Up and Locked Out? The Impact of Imprisonment on Labour Market Attachment', The British Journal of Criminology 2017-58(5), p. 1044-1065.

Becker, G., 'Crime and punishment: an economic approach', Journal of Political Economy 1968-76(2), p. 169-217.

Beerthuizen, M.G.C.J., K.A. Beijersbergen, S. Noordhuizen \& G. Weijters, Vierde meting van de monitor nazorg ex-gedetineerden. Cahiers 2015-11. Den Haag: Wetenschappelijk Onderzoek- en Documentatiecentrum 2016.

Beleidsregels VOG-NP-RP, 2004.

Beleidsregels VOG-NP-RP, 2008.

Beleidsregels VOG-NP-RP, 2013.

Beleidsregels VOG-NP-RP, 2018.

Berg, M.T. \& B.M. Huebner, 'Reentry and the ties that bind: An examination of social ties, employment, and recidivism', Justice Quarterly 2011-28(2), p. 382-410.

Boekhoorn, P., T. Verhaegh \& M. Wolbers, Het aanvragen van een Verklaring Omtrent het Gedrag door jongeren als dilemma. Een schatting van het 'dark number' van niet-aanvragers van een VOG voor opleidingen in het middelbaar beroepsonderwijs. Nijmegen: KBA/BBSO 2019.

Boone, M., 'Judicial rehabilitation in the Netherlands: Balancing between safety and privacy', European Journal of Probation 2011-3(1), p. 63-78.

Boone, M., "Gestraft" na de straf. Legaliteit en proportionaliteit van juridische belemmeringen na afloop van de straf', Proces 2012-91(2), p. 103-114.

Boone, M. \& E.G. Kurtovic, Bijkomende gevolgen van straf en het principe van proportionele strafoplegging, Nederlands Juristenblad 2016-91(23), p. 1623-1629.

Brok, H., Gevangen in het verleden, Utrecht: Wetenschapswinkel Rechten 1999.

Bushway, S., 'The problem of prisoner (re)entry'. Contemporary Sociology 2006-35(6), p. 562- 565.

Bruning, M., De VOG en minderjarige wetsovertreders' Proces 2012-91(2), p. 128-137.

Buysse, W., S. Meijer \& B. Szytniewski, Pre-employment screening in de grensregio's van de Benelux en Duitsland, Amsterdam: DSP-groep 2018.

Centraal Bureau voor Statistiek, Werkgelegenheid; geslacht, dienstverband, kenmerken werknemer (SBI2008), cijfers van 2018.

Cohen, L.E. \& M. Felson, 'Social change and crime rate trends: a routine activity approach', American Sociological Review 1979-44(4), p. 588-608.

Dienst Justitiele Instellingen 2019. Gevangeniswezen. www.dji.nl/binaries/ 120687_03_dji_infosheet_gevangeniswezen_april_2019_V4_tcm41-352270.pdf.

Dirkzwager, A.J., P. Nieuwbeerta, K. Beijersbergen, A. Bosma, R. de Cuyper, J. Doekhie, V. Eichelsheim, S. de Goede, P. van der Laan, W. Lamet, H. Palmen, E. Raaijmakers, A. Ramakers, J. Reef, S. van der Stelt, M. Wensveen \& H. Wermink, 'Cohort profile: the prison project - a study of criminal behavior and life circumstances before, during, and after imprisonment in the Netherlands', Journal of developmental and life-course criminology 2018-4(1), p. 120-135.

Dirkzwager, A.J.E., P. Nieuwbeerta \& J.P.S. Fiselier, 'Onbedoelde gevolgen van vrijheidsstraffen', Tijdschrift voor Criminologie 2009-51(1), p. 21-41.

Fletcher, D.R., 'Offenders in the Post-Industrial Labour Market: From the Underclass to the Undercaste?' Policy \& Politics 2008-36(2), p. 283-297.

Graffam, J., A.J. Shinkfield \& L. Hardcastle, 'The perceived employability of ex-prisoners and offenders', International Journal of Offender Therapy and Comparative Criminology, 2008-52(6), p. 673-685. 
Gosliga, F.P., De stem van de uitvoering in perspectief. Een experimentele verkenning van de beleving van risicojongeren en jeugdprofessionals rond de aanvraag van de VOG. Almere: SenseGuide 2015.

Justis 2018. Kwartaalcijfers 2018 - VOG-NP en VOG voor vrijwilligers. Geraadpleegd via www.justis.nl/overjustis/cijfers/2018/vog.aspx.

Kamerstukken II 2008/9, 29911, nr. 25.

Kamerstukken II 2010/11, 33000-VI, nr. 73.

Kamerstukken II 2016/17, 34550 VI, 98.

Kruize, P. \& P. Gruter, Eens een dief, altijd een dief? Een verkenning rond het meten van de effectiviteit van de Verklaring Omtrent het Gedrag, Den Haag: WODC 2016.

Kurtovic, E.G., 'Krijgt mijn kind een strafblad? De Verklaring Omtrent het Gedrag in de Praktijk', Tijdschrift Jeugdrecht in de Praktijk 2015(5), p. 20-25.

Linckens, P. \& J. de Looff, Gevangeniswezen in getal 2008-2012. Den Haag: Dienst Justitiële Inlichtingen, Ministerie van Veiligheid en Justitie 2013.

Meijer, S., 'De Verklaring Omtrent Gedrag; enkele kanttekeningen bij recente rechtspraak'. Delikt en Delinkwent 2015-32(4), p. 323-334.

Meijer, S., 'De invloed van de strafrechter op de bijkomende gevolgen van de straf.' Delikt en Delinkwent 2017-34(3).

Miller, J., Individual offending, routine activities, and activity settings: revisiting the routine activity theory of general deviance', Journal of Research in Crime and Delinquency 2013-50(3), p. 390-416.

Pager, D., 'The mark of a criminal record', American journal of sociology 2003-108(5), p. 937-975.

Ramakers, A., P. Nieuwbeerta, J. van Wilsem, A.J.E. Dirkzwager \& J. Reef, 'Werk (kenmerken) en recidiverisico's na detentie in Nederland', Tijdschrift voor Criminologie 2014-56(2), p. 67-89.

Ramakers, A., P. Nobbe, P. Nieuwbeerta \& A. Dirkzwager, 'Zwart werk na vrijlating', Mens en maatschappij 2017-92(1), p. 7-33.

Ramakers, A., J. van Wilsem, P. Nieuwbeerta \& A. Dirkzwager, 'Down before they go in? Pre-prison labor market attachment in the Netherlands', European Journal of Criminal Policy and Research 2015-21(1), p. 65-82.

Raphael, S., 'Incarceration and prisoner reentry in the United States', The annals of the American academy of political and social science 2011-635(1), p. 192-215.

Sampson, R.J. \& J.H. Laub. Crime in the making: pathways and turning points through life, Cambridge, MA: Harvard University Press 1993.

Singer-Dekker, H., Justitiële documentatie en antecedentenonderzoek, Zwolle: W.E.J. Tjeenk Willink 1980.

Uggen, C., 'Ex-offenders and the conformist alternative: a job quality model of work and crime', Social Problems 1999-46(1), p. 127-151.

Valk, M.C., H. Roth, M. Haak \& X. Sam-Sin, Evaluatie afgifte VOG NP, Amsterdam: ERGO: bureau voor markt- en beleidsonderzoek 2006.

Van 't Zand, E.G., Invisible bars; The impact of having a criminal record on young adults' position in the labour market (diss), Willem Pompe reeks, 88. Den Haag: Eleven International Publishing 2017.

Van 't Zand, E.G., 'Ruim baan? Uitsluiting en zelfuitsluiting van de arbeidsmarkt', Justitiële verkenningen 2018-44(2), p. 117-132.

Van der Geest, V., C. Bijleveld \& A. Blokland, 'The effects of employment on longitudinal trajectories of offending: A follow-up of high-risk youth from 18 to 32 years of age', Criminology 2011-49(4), p. 1195-234. 
Van der Klein, M., V. Los \& R. Verwijs, In veilige handen met gratis VOG. Evaluatieonderzoek integriteitinstrumenten ter voorkoming van seksueel overschrijdend gedrag in het vrijwilligerswerk, Utrecht: Verwey-Jonker instituut 2013.

Visher, C., S. Debus \& J. Yahner, Employment after release: A longitudinal study of releasees in three states, Washington, DC: The Urban Institute, Justice Policy Center 2008.

Wildemors, R., 'De beoordeling van een VOG-aanvraag', Proces 2012-91(2), p. 82-88. 